\title{
SOSIALISASI PENGGUNAAN BLOG SEBAGAI STRATEGI PEMASARAN BUAH PINANG DI DESA SIDODADI
}

\author{
Khairunnisa ${ }^{1}$, Siti Sundari ${ }^{2}$, Ade Irwan ${ }^{3}$ \\ 1,2,3 Universitas Harapan Medan \\ e-mail: khairunnisajv2@gmai.com¹ sundaristth@gmail.com² $^{2} \underline{\text { adeirwan006@gmail.com }^{3}}$
}

\begin{abstract}
Sidodadi Village is a village in the Batang Kuis sub-district, Deli Serdang Regency, North Sumatra Province, Indonesia. One of the businesses in Sidodadi village is the Home Industry for marketing betel nuts which was initiated in 2012 by Mr. Mahadi and his wife, Mrs. Yayuk Wulan Dari. From the survey results, it turns out that partners have several problems, including the lack of knowledge and skills possessed by partners regarding product marketing techniques. The marketing method used by partners is still conventional, namely offering products by conveying information about their products and trying to persuade consumers to want to buy. During the covid pandemic, like today, partners feel the sales of betel nuts are decreasing. Therefore, partners need several steps to be able to maintain the business that the partners have built so far. The step or solution offered to partners is to use internet services, namely by providing socialization on the use of blogs to increase the marketing of areca nuts owned by partners.
\end{abstract}

Keywords: Sidodadi Village, Areca Fruit, Marketing Blog

\begin{abstract}
Abstrak
Desa Sidodadi adalah desa wilayah kecamatan Batang Kuis Kabupaten Deli Serdang Provinsi Sumatera Utara, Indonesia. Salah satu usaha desa Sidodadi adalah Industri Rumah Tangga pemasaran buah pinang yang mulai dirintis sejak tahun 2012 oleh Bapak Mahadi dan istrinya ibu Yayuk Wulan Dari. Dari hasil survei yang telah dilakukan ternyata mitra memiliki beberapa persoalan yang dihadapi, antara lain minimnya pengetahuan dan keterampilan yang dimiliki oleh mitra mengenai teknik pemasaran produk. Metode pemasaran yang dilakukan oleh mitra masih tergolong konvensional yaitu menawarkan produk dengan menyampaikan informasi tentang produknya dan berupaya membujuk konsumen agar mau membeli. Dimasa pandemic covid seperti saat sekarang ini mitra merasakan penjualan buah pinang sangat menurun. Oleh karena itu mitra memerlukan beberapa langkah untuk dapat mempertahankan bisnis yang selama ini mitra bangun. Langkah atau solusi yang ditawarkan kepada mitra adalah dengan menggunakan layanan internet yaitu dengan memberikan sosialisasi penggunaan blog untuk meningkatkan pemasaran buah pinang yang dimiliki oleh mitra.
\end{abstract}

Kata Kunci: Desa Sidodadi, Buah Pinang, Blog Pemasaran

\section{PENDAHULUAN}

Perkembangan industri kecil dan menengah di Indonesia telah mengalami peningkatan yang cukup signifikan. Hal ini tidak luput dari peran serta pemerintah daerah maupun pusat yang terus menerus melakukan pembinaan dan bantuan lainnya. Berbagai upaya pembinaan dilakukan untuk mengembangkan industri kecil, mengingat potensinya yang sangat mendukung perekoniman masyarakat Indonesia. Usaha mikro, dan menengah juga 
merupakan salah satu unsur penting dalam menopang perekonomian nasional secara menyeluruh. Seperti yang dijelaskan Oleh (Yuli, 2017) Usaha Kecil adalah usaha ekonomi produktif yang berdiri sendiri, yang dilakukan oleh orang perorangan atau badan usaha yang bukan merupakan anak perusahaan atau bukan cabang perusahaan yang dimiliki, dikuasai, atau menjadi bagian baik langsung maupun tidak langsung dari Usaha Menengah atau Usaha Besar.

Jenis usaha mikro dapat membantu pemerintah dalam hal menciptakan lapangan pekerjaan dan mengurangi tingkat pengangguran. Apalagi dimasa pandemic covid seperti sekarang ini, tidak sedikit bagi masyarakat yang membutuhkan pekerjaan untuk menambah pendapatan perekonomian keluarganya. Salah satu usaha mikro yang membuka lapangan pekerjaan adalah usaha rumah tangga penjualan buah pinang yang ada di desa Sidodadi Sumatera Utara. Desa Sidodadi adalah desa yang terletak di wilayah kecamatan Batang Kuis Kabupaten Deli Serdang Provinsi Sumatera Utara, Indonesia. Dilihat dari sumber daya yang ada Desa Sidodadi memiliki sumber daya yang memiliki potensi yang baik untuk mengembangkan usaha. Salah satu usaha yang ada di Desa Sidodadi adalah usaha penjualan buah pinang yang mana biji pinang di produksi dan dipasarkan oleh Bapak Mahadi bersama istrinya Ibu Yayuk Wulan Dari. Bapak Mahadi adalah salah satu warga Desa Sidodadi yang telah merintis usahanya sejak tahun 2012 yang dibangun bersama istri dan orang tuanya.

Buah pinang dijelaskan sebagai tanaman yang banyak manfaat dan khasiat, terutama bijinya. Biji pinang banyak dimanfatkan sebagai bahan baku utama dalam proses pembuatan obat, kosmetik, pelangsing, makanan ringan, permen, dan kopi. Di Indonesia tanaman pinang banyak terdapat di pulau Sumatera (Aceh, Sumatera Utara dan Sumatera Barat), Kalimantan (Kalimantan Selatan dan Kalimatan Barat), Sulawesi (Sulawesi Selatan dan Sulawesi Utara) dan Nusa Tenggara (Nusa Tenggara Barat dan Nusa Tenggara Timur). (Ringdengan, 2007)

Biji pinang memiliki banyak manfaat, seperti penelitian (Nur Afni, dkk, 2015) mengatakan bahwa Biji pinang mengandung senyawa alkaloid, flavonoid, tanin, saponin, dan polifenol yang diketahui berkhasiat sebagai antibakteri.

Pinang dikenal sebagai tanaman industri yang banyak manfaatnya bagi manusia. Karena mulai dari akar sampai buah semuanya dapat dimanfaatkan untuk kebutuhan manusia. Pinang merupakan sumber tanin yang tinggi sehingga banyak manfaatnya dalam industri farmasi. Pinang banyak digunakan untuk campuran obat-obatan tradisioal dan bahkan diolah manjadi pewarna alami. Di samping itu biji pinang merupakan benda yang sangat mudah untuk di perdagangkan di dalam dan luar negeri dan dapat disimpan dalam jangka 
waktu yang cukup lama, kandungan utama pada buah pinang yaitu karbohidrat, serat, lemak, alkaloid, mineral, serta polifenol yang meliputi flavonoid dan tannin. (Fergiawan, Ali, 2020)

Buah pinang (areca cathecu) merupakan salah satu komoditas ekspor Indonesia. Pinang yang menjadi komoditas ekspor tersebut adalah pinang yang sudah berbentuk biji atau yang sudah terkupas sabut dari batoknya. (Deni Alfian, dkk, 2018 ) Hasil survei pendahuluan yang pengusul lakukan menunjukkan bahwa kemajuan usaha budidaya buah pinang di Desa sidodadi relatif kurang baik. Hal ini disebabkan beberapa faktor antara lain kurangnya peralatan dalam proses produksi pengupasan buah pinang sehingga membuat pendapatan perhari kurang maksimal. Pemilik usaha buah pinang ini juga hanya memiliki satu tempat penampung hasil biji pinangnya. Oleh karena itu sangat dibutuhkan sistem strategi pemasaran yang lebih efektif dengan tujuan produksi biji buah pinang meningkat dan memberikan kemudahan bagi Mitra untuk mempromosikan buah pinang melalui internet. Melihat hasil survei tersebut maka pengusul memberikan solusi kepada pemilik usaha untuk membantu membuatkan sistem pemasaran yang lebih luas lagi. Oleh karena itu, pengusul bersama-sama mitra mengidentifikasi bahwa sangat perlu dilakukannya peningkatan soft skill dan ketrampilan bagi para pengusaha buah pinang di Desa Sidodadi, yang bisa dilakukan melalui pendidikan, pelatihan dan aplikasi dalam program Pengabdian kepada Masyarakat Sosialisasi Penggunaan Blog Sebagai Strategi pemasaran buah pinang.

\section{METODE}

Rencana kegiatan yang akan dilakukan dalam Program Kemitraan Masyarakat bertempat didusun II Desa Sidodadi Kecamatan Batang Kuis Kabupaten Deli Serdang Sumatera Utara.

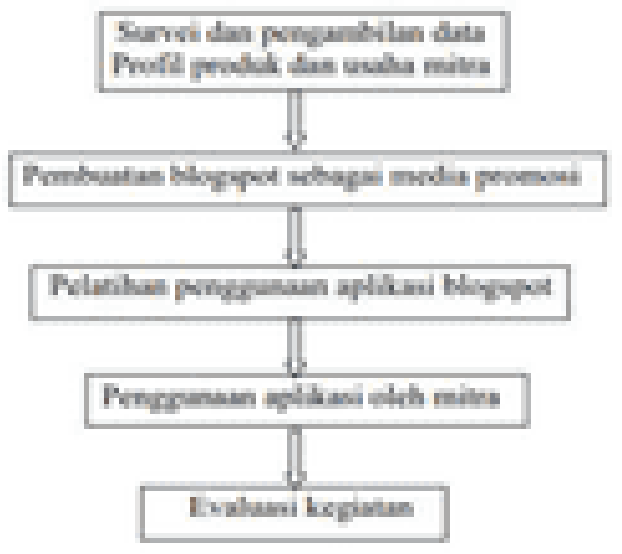

Gambar 1. Bagan Kegiatan Sistem Promosi 
Secara rinci tahapan kegiatan yang akan dilakukan meliputi:

a. Tahap Persiapan Tahap persiapan yang dilakukan adalah

1. Survei, pemantapan dan penentuan lokasi, sasaran serta penentuan permasalahan yang dihadapi oleh mitra.

2. Evaluasi permasalahan dan penentuan solusi yang ditawarkan dan disepakati bersama mitra.

3. Penyusunan materi dan kelengkapan kegiatan.

b. Tahap pelaksanaan diklat dan penyuluhan, meliput:

1. Pembuatan blogspot dan pelatihan penggunaan media sosial sebagai media pemasaran yang efektif dan efisien.

2. Aplikasi teknologi dan evaluasi hasil aplikasi teknologi

c. Tahap Evaluasi

Tahap evaluasi diperlukan untuk menganalisis tingkat keberhasilan kegiatan, mulai dari persiapan, proses hingga capaian hasil kegiatan. Partisipasi mitra dalam pelaksanaan program ditunjukkan dengan adanya dukungan dan kesanggupan kerja sama sebagai mitra dengan tim dari Universitas Harapan Medan dalam Program Kemitraan Masyarakat. Partisipasi mitra ini ditunjukkan melalui pelaksanaan kegiatan secara bersama-sama dalam hal penyiapan lokasi kegiatan, pelaksanaan kegiatan uji peralatan dan penyediaan data untuk analisis.

\section{HASIL DAN PEMBAHASAN}

Hasil yang dicapai dari pelaksanaan kegiatan Sosialisasi Penggunaan Blog Sebagai

Strategi pemasaran buah pinang di Desa Sidodadi adalah:

1. Meningkatkan Pemahaman Kepada Mitra dalam penggunaan Blogspot yang telah diberikan oleh TIM PkM.

2. Pihak Mitra dapat memaksimalkan kegiatan usahanya melalui penggunaan blog.

3. Memberikan metode baru dalam pemasaran Buah Pinang untuk meningkatkan hasil pemasaran setiap bulannya.

4. Pelatihan merupakan sarana terbaik dalam memberikan penjelasan kepada mitra mengenai bahan pembelajaran yang dibutuhkan mitra dalam penggunaan Blog. 


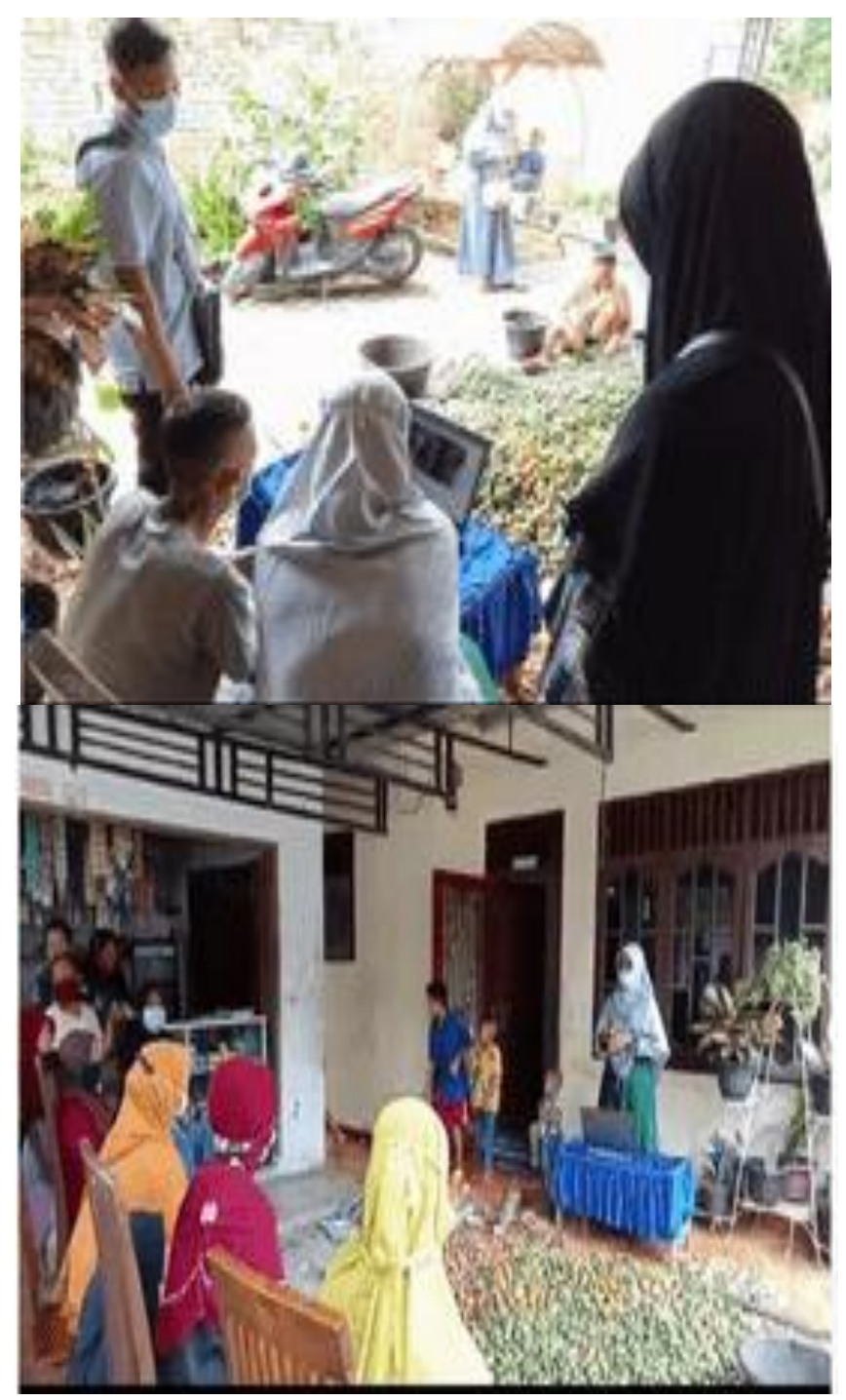




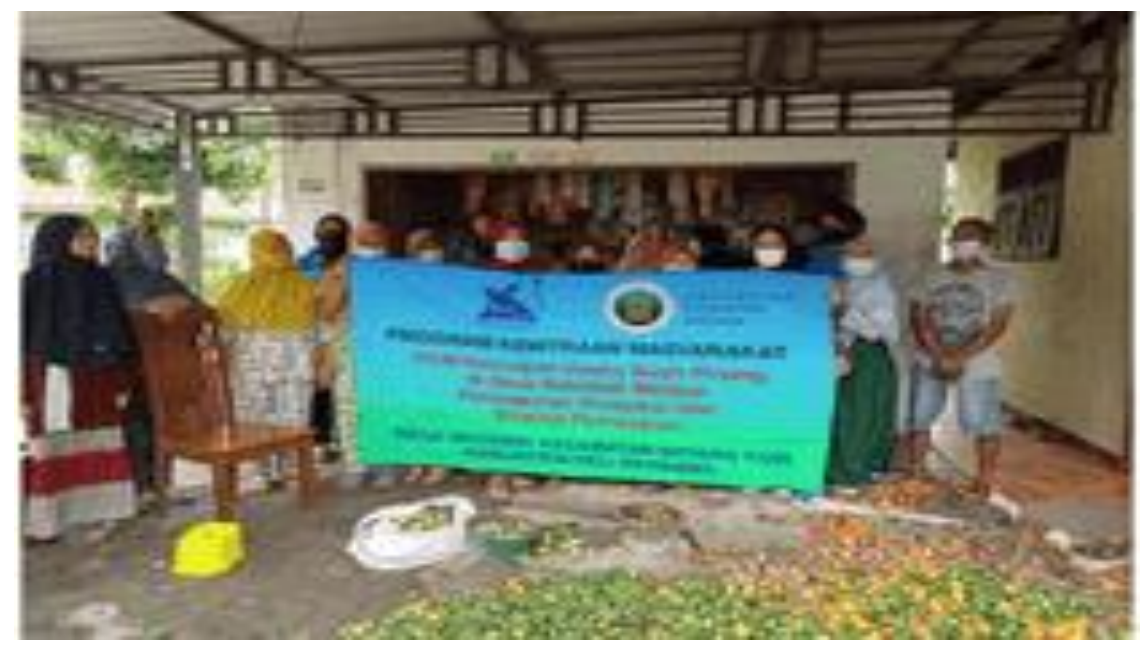

\section{Gambar 2. Kegiatan Sosialisasi Penggunaan Blog}

Sebagai Strategi pemasaran buah pinang

Adapun hasil dari kegiatan Sosialisasi ini adalah memberikan sistem pemasaran yang dibangun melalui Blogspot sebagai strategi pemasaran buah pinang. Dimana hasil blog yang didapatkan ini akan membantu pemasaran buah pinang menjadi lebih luas lagi sehingga pendapatan mitra lebih meningkat dari sebelumnya. Berikut tampilan Home pada Blog.
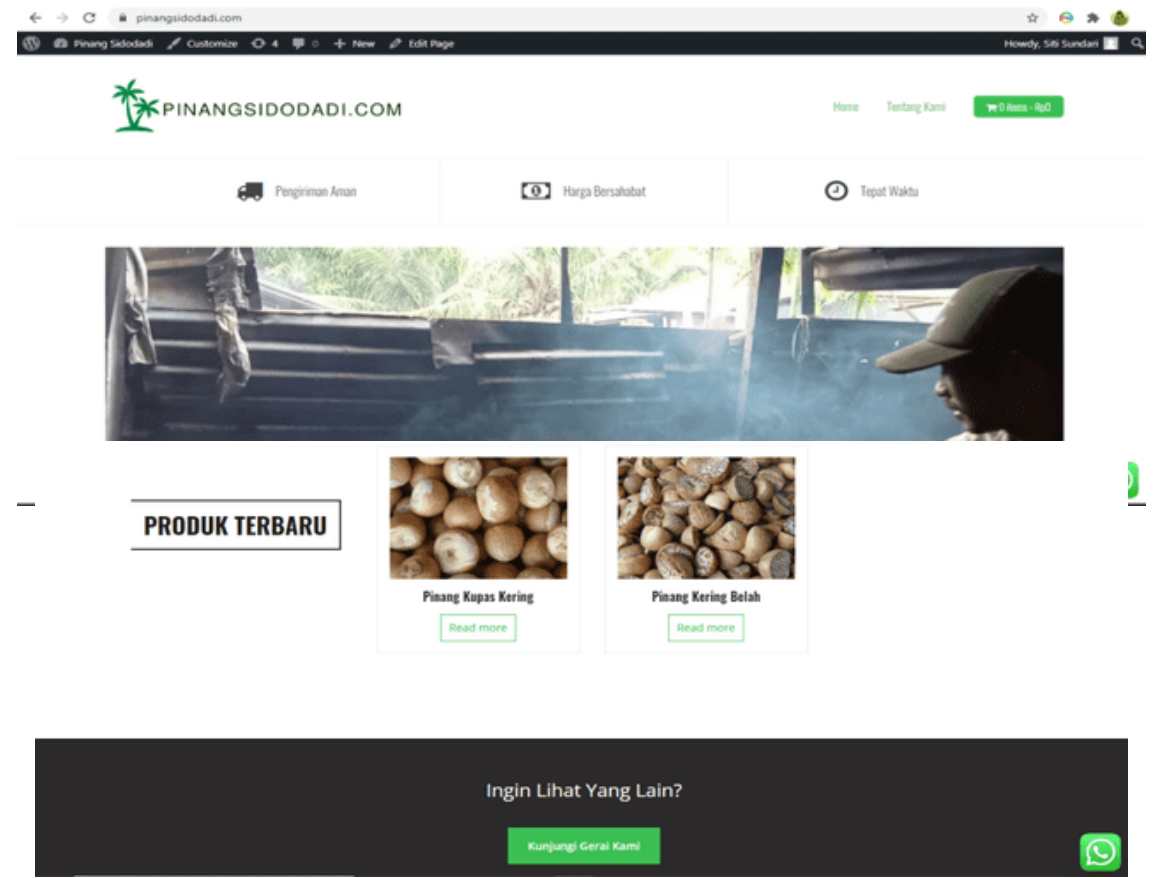

Gambar 3. Home Pada Blog PinangSidodadi 


\section{Gambar 4. Tentang Kami Pada Blog PinangSidodadi}

\section{KESIMPULAN}

Dampak pandemi Covid 19 sangat berimbas di semua kalangan, termasuk di industri rumah tangga milik lbu Yayuk dan Bapak Mahadi yang memiliki usaha buah pinang. Kendala yang dihadapi yaitu mengenai penjualan biji buah pinang yang belum maksimal. Dari kendala tersebut, peneliti memberikan solusi yaitu pembuatan blog untuk memaksimalkan penjualan buah pinang. Pelatihan pemasaran online juga menjadi terobosan solusi mengatasi kendala yang ada.

\section{DAFTAR PUSTAKA}

Yuli Rahmini Suci, 2017. Perkembangan Umkm (Usaha Mikro Kecil Dan Menengah) Di Indonesia. Jurnal IImiah Cano Ekonomos Vol. 6 No. 1 Sekolah Tinggi Ilmu Ekonomi Balikpapan.

Rindengan Barlina, 2007. Peluang Pemanfaatan Buah Pinang Untuk Pangan Opportunity of Arecanut for Food Utilizing. Balai Penelitian Tanaman Kelapa dan Palma Lain

Nur Afni1, Nasrah Said, Yuliet, UJI AKTIVITAS ANTIBAKTERI PASTA GIGI EKSTRAK BIJI PINANG (Areca catechu L.) TERHADAP Streptococcus mutans DAN Staphylococcus aureus, GALENIKA Journal of Pharmacy Vol. 1 (1): 48 - 58 ISSN: 2442-8744

Fergiawan Izamas Putra, Ali Basrah Pulungan, 2020. Alat Pengering Biji Pinang Berbasis Arduino, JTEV (JURNAL TEKNIK ELEKTRO DAN VOKASIONAL) Vol.6 No. 1 ISSN: 2302-3309

Deni Alfian, dkk, 2018 Membuat Mesin Pengupas Kulit Buah Pinang Kering. Jurnal Mesin Sains Terapan Vol.2 No.1 Politeknik Negeri Lhokseumawe. 